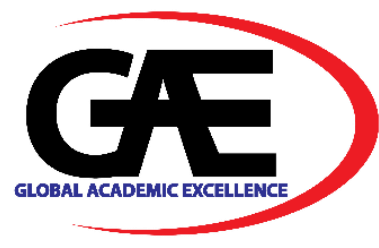

\title{
THE DETERMINANT FACTORS THAT INFLUENCE THE GENERATIONS Z AND OLDER GENERATIONS IN MALAYSIA TOWARD CASHLESS SOCIETY
}

Hirnissa, M.T ${ }^{1}$, Zariyawati, M.A ${ }^{2^{*}}$, Fadilla, R. ${ }^{3}$

1 Faculty of Business, Accounting and Social Science, Kolej Universiti Poly-Tech Mara Kuala Lumpur, Malaysia Email: hirnissa@kuptm.edu.my

2 School of Business and Economic, Universiti Putra Malaysia, Malaysia

Email: zariyawati@upm.edu.my

3 Faculty of Business, Accounting and Social Science, Kolej Universiti Poly-Tech Mara Kuala Lumpur, Malaysia Email: fadilla@kuptm.edu.my

* Corresponding Author

\section{Article Info:}

\section{Article history:}

Received date: 25.04 .2021

Revised date: 30.06 .2021

Accepted date: 18.07.2021

Published date: 01.09.2021

\section{To cite this document:}

Hirnissa, M. T., Zariyawati, M. A., \& Fadilla, R. (2021). The Determinant Factors That Influence The Generations Z And Older Generations In Malaysia Toward Cashless Society. Advanced International Journal of Business, Entrepreneurship and SMEs, 3 (9), 22-35.

DOI: $10.35631 /$ AIJBES.39003.

This work is licensed under $\mathrm{CC}$ BY 4.0

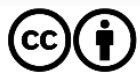

Abstract:

This study highlights the key predictors that influence Malaysia's cashless society rate. Unified Theory of Acceptance and Usage of Technology (UTAUT) was adopted in this research, and main constructs such as speed of transaction, personal security, convenience and safer, social influences, perceived usefulness, compatibility, business readiness, and financial costs. The sample size for this study is 357 Malaysian aged 18 years old and above. There are two generations under 25 years old and below categorized as Generations Z, while age 25 years old and above are categorized as Older Generations. Primary data had been used and collected through an online questionnaire method. Using SPSS software, regression analysis results showed that four of the independent variables had a significant relationship with the dependent variables. The speed of transaction, convenience and safer, perceived usefulness, and compatibility did influence Malaysian towards cashless society adoption.

Keywords:

Generation Z, Cashless, UTAUT, TAM 


\section{Introduction}

Cash is the physical form of money. There are few drawbacks of using cash which can mitigate if the users move towards cashless payment because easy to use by users and better security. Today, the mobile payment (mPayment) method gives more improvement, such as the transaction speed and saving time rather than non-traditional transactions. There will also be increased personal security when there is no cash because robberies and thefts could be reduced. The feeling of insecurity and crime could be reduced by not carrying money in coins or cash. Then, foreign currency is unnecessary when traveling because money will be transferred electronically (Anyaegbunam, 2014). Thus, cashless payment is preferred to cash payment because cashless payment is convenient and safer.

Even though cashless payment is convenient and safer but not all people willing to change to a cashless transaction. The age factor will influence the cashless society. Generations $\mathrm{Z}$ is more likely to use digital financial services, as they are easier to embrace technological changes and are more open to technology such as mobile use (Trinugroho et al., 2017). Further, social influences also can be determinants of a cashless society when the people around us use cashless methods such as e-wallet or debit card to make payments. Furthermore, with an easy technology system like the cashless approach, consumers can reduce cash usage in purchasing goods or utility payments (Chelawat \& Trivedi, 2014). The perceived usefulness also affects the adoption of cashless transactions and has influenced customers' intention to use an electronic wallet (Yadav, 2017). Hence, it encourages more customers to use this service in this era of a cashless economy.

Besides, compatibility, which refers to innovation, is consistent with the prospective user's lifestyle, values, and behaviors also determine the adoption of a cashless society. The design of mPayment processes is compatible with users' shopping behaviors (Rogers, 1995). The importance of knowledge in the early stage of innovation diffusion, especially when the users and the peer group have a few new technology experiences (Taylor \& Todd, 1995). Thus, epayment knowledge is needed for individuals who used the latest technology system, such as cashless transactions. Nowadays, people should know about technology because almost all places use systems to communicate with people, produce, purchase products and services. The higher the respondents' education, the higher the plan to implement new technologies like finance technologies (Amin, Hamid, Lada, and Anis (2008)).

Other factors like income, education, homeownership, marital status, and job level (managerial, professional, technical, and administrative occupations) were all linked to the use of electronic transactions (Rui Jin, 2005). Consumers with higher incomes are also more likely to be using debit cards. This supports the spread of innovation theory, suggesting that younger and wealthier consumers are inclined to try new products such as cashless payments or transactions. Individuals with higher labor incomes may have higher time- opportunity costs and may be able to pay more for a quicker transaction. To conclude, several factors influence generation $\mathrm{Z}$ and older generations toward a cashless society. For example, the transaction speed, personal security, convenience and safer, social influences, perceived usefulness, compatibility, business readiness, and financial cost. The introduction of new technologies, which as cashless payment, gives more advantages or benefits to the users. Mostly the users already know about cashless payment but not willing to change to the cashless society. Hence, the current study investigates the determinant factors which influence Malaysian towards a cashless society. Further, compare whether there are any different factors between generations $\mathrm{Z}$ and older 
Volume 3 Issue 9 (September 2021) PP. 22-35

DOI 10.35631/AIJBES.39003

generations to adopt a cashless society. Perhaps, this study should help society, such as businesses and consumers, become conscious of the evolution of the cashless society and help them brace themselves better for the changes to a cashless society.

\section{Literature Review}

Worthington (1995) defined a cashless society as replacing clumsy and expensive to handle coins and notes with the efficient electronic payments initiated by various types of plastic cards. Anyaegbunam (2014) claimed a cashless society could eliminate paper banknotes and checks, but it would not eliminate money. Thus, cashless is simply meant by electronic transactions. Lazo, Karlsson \& Thodenius (2014) said that a cashless society requires the digitalization of inside and outside financial institutions' activities. The early step in digitalization depends on a group of organizational processes and emergent technologies, such as direct-to-account payments and cash dispensers.

Swartz, Hahn \& Farrar (2006) emphasized that cash and checks are still in use, but certain payment cards are growing faster than paper instruments. Later, Anyaegbunam (2014) said introducing electronic cash-based electronic commerce is the key engine driving global economic activity that later decides society's future form. He added that some electronic instruments are now well established, such as debit and credit cards.

However, Trinugroho et al. (2017) said that a society with less readiness would cause digital financial services not to be effective. The cashless society's development is growing rapidly over time and becoming a favorite research topic. For many years, it has been believed that cash use has been slowly decreasing, with the push toward a cashless economy underway. This is described as "an environment in which money is spent without being physically transferred from one person to another" (Ejoh et al., 2014). Tee \& Ong (2016) claim cashless payment technology is driven by evolution in IT. That technological innovation has changed the payment system's perspective and shows that they are now drifting more towards an electronic world.

Nuwagaba (2014) suggests that the hardest thing to accomplish is a cashless society if a country does not have an efficient communication network. The question is that people may not prefer electronic transactions. Tee \& Ong (2016) said, "Private information leakage that undermines consumer trust in making electronic payments." This means cash for personal preferences will still be around and used in society. A recent US study found that a rise in cashless transactions resulted in lower burglaries and decreased overall crime rate (Achord et al., 2017).

Electronic money payment can be processed easily, and there is no common problem like queues (Wulandari, Soseco, \& Narmaditya 2016). Electronic money is transferred within seconds from the payer to the receiver and has significant advantages compared to cash, but it also has disadvantages. According to transaction cost theory, consumers face two major challenges when making purchasing decisions: budget and time constraints. Besides, customers prefer to optimize purchases' value to avoid additional money and time costs (Rajiv, Sarv \& Adam, 2014). Anyaegbunam (2014) said it prevents currency forgery in a cashless society, and people are getting the exact value for their goods. 
Volume 3 Issue 9 (September 2021) PP. 22-35

DOI 10.35631/AIJBES.39003

Perceived usefulness is a strong predictor of the goal and attitude towards the use of electronic money (Filona \& Misdiyono, 2019). Perceived usefulness also has a significant impact and appears to be the second determinant of consumers' attention by adopting an electronic money attitude. The hypothesis showed that consumers' perceptions of compatibility with mobile payments positively impact mobile payment services adoption (Liebana-Cabanillas et al., 2015). Wright (2010) found that rival retailers only accept payment cards because it helped them gain higher margins. That finding came about because customers were willing to pay more for the product when customers could purchase via card.

Odumeru (2013) research shows that mobile banking is more common than other age groups for individuals aged between 21 and 40. Subsequently, Trinugroho et al. (2017) further endorsed his research result showing that age has a negative and important connection to readiness. They explained further that younger people are more willing to use digital financial services. The scholars believe that the use, implementation, and evaluation of the new technology is relatively easier for users, irrespective of its uncertainty, only if people understand the technology beforehand (Chmielarz \& Zborowski, 2018). Nowadays, when many social activities and interactions take place through mobile phones, mobile phones can also be considered a life-needed item for and person. The subsequent introduction of debit cards, credit cards, cell phones, and mobile banks gradually led to electronic payment, which was crucial to meet the cashless society's goal (Pritchard, 2019).

\section{Theoretical Framework}

The figure below shown the theoretical framework of this study of which determinant factors towards a cashless society. All these factors will be hypothesized and tested to examine the determinant factors influencing generation $\mathrm{Z}$ and older generations toward a cashless society. ST, PS, CS, SI, PU and C are extracted from Unified Theory of Acceptance and Use of Technology (UTAUT) and Technology Acceptance Model (TAM), a famous and comprehensive model in assessing technology adoption. BR and FC are the extension factors added by the researcher extracted from Perceived e-Readiness Model (PERM). This model has been categorized into Perceived Organizational e-Readiness (POER) and Perceived External e-Readiness (PEER). 
Figure 1: Determinant Factors Towards Cashless Society

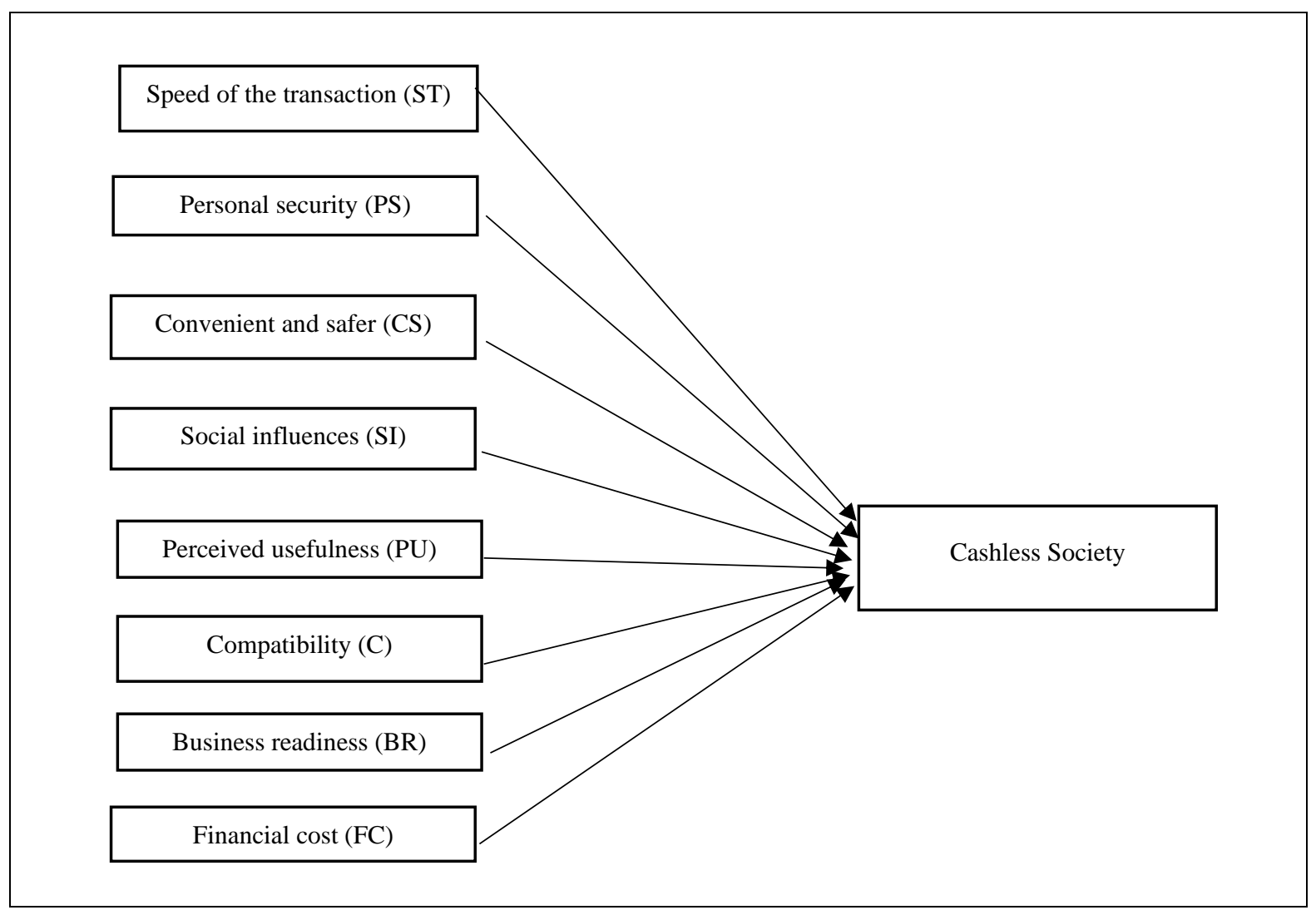

Performance expectancy can relate with the transaction speed (ST) where an individual believes that cashless society adoption will increase his/her efficiency in performing his/her task (Venkatesh et al., 2012). Personal protection (PS) is one way to make customers trust other technologies. It can secure and separate issues into three aspects: honesty, availability, and confidentiality, which are used as solutions in technical practice and managerial operation. Convenience $(\mathrm{C})$ can be seen as positive correlation between perceived utility and userfriendliness with the potential for digital money adoption. Pointed out that cashless payment methods provide customers with a record-keeping tool that is useful for budgeting, planning, and preparing income tax. Social influence (SI) is crucial to shaping the behavior of users. For example, based on a review of the extant literature, UTAUT is a comprehensive synthesis of prior technology acceptance research (Venkatesh et al., 2003). Here, social influence is the extent to which consumers perceive that significant people, such as family and friends, feel that they should use a particular technology. Perceived usefulness (PU) is the degree to which mobile payment users will improve their output level by implementing the technologies such as mobile payment users. Compatibility has been defined in adopting new technologies as the consistency of innovation with its values, experiences, and needs of potential adopters (Rogers, 1995). The compatibility factor involves the continuity of an invention with an individual's beliefs, behavior patterns, and experiences (Liebana-Cabanillas et al., 2015). Business readiness (BR) is handling change within the organization, such as new structures, technologies, or processes that impact the organization. Financing costs (FC) are defined as the company's interest and other costs while borrowing funds. 


\section{Methodology}

Primary data is distributed to collect relevant information to gain insights on determinant factors towards a cashless society. Due to the limitations, the researcher cannot obtain the sampling frame (a complete list of cashless society). Non- probability sampling will be more appropriate in conducting this research. Thus, a convenience sampling technique will be used for the data collection of relevant information.

A questionnaire structured and designed by the researcher refers to previous research to produce a great quality questionnaire that is understandable and maximizes response rates. This study focuses on users or individuals with debit cards, credit cards, online banking accounts, or any other means indicating usage of cashless payment. The population is set based on criteria identified as follows age 18 years old and above, live in Malaysia, and study or work in Malaysia. The targeted sample also suggested being 18 years old and above from different gender, income level, education level, and age range to obtain more generalized data for research topic and objectives.

This study using the Multiple regression analysis using Statistical Package for Social Sciences (SPSS) software to transform numerical data into statistical view and generate insights for research topics and objectives. Before testing multiple regression, we also test descriptive analysis, reliability test, normality test, and Pearson correlation analysis.

Hair (2006) suggests that multiple regression analysis is a statistical approach that studies the linear relationship between independent and dependent variables by estimating the equation's coefficients and forming a straight line. The equation in multiple regressions is:

$Y=\beta 1+\beta 1 X 1+\beta 2 X 2+\ldots \ldots+\beta n X n$

For this study, multiple regressions will be used to analyze the eight independent variables influencing Generation $\mathrm{Z}$ and older generations toward Malaysia's cashless society. Thus, the equation formed for this study is:

$\mathrm{CS}=\beta 0+\beta 1 \mathrm{ST}+\beta 2 \mathrm{PS}+\beta 3 \mathrm{CS}+\beta 4 \mathrm{SI}+\beta 5 \mathrm{PU}+\beta 6 \mathrm{C}+\beta 7 \mathrm{BR}+\beta 8 \mathrm{FC}$

Whereby,

$C S=$ Cashless society (Dependent Variable)

$S T=$ Speed of transactions (Independent Variable 1)

$P S=$ Personal security (Independent Variable 2)

$C S=$ Convenience and safer (Independent Variable 3)

$S I=$ Social influences ((Independent Variable 4)

$P U=$ Perceived usefulness (Independent Variable 5)

$C=$ Compatibility (Independent Variable 6)

$B R=$ Business Readiness (Independent Variable 7)

$F C=$ Financial Cost (Independent Variable 8) 


\section{Results}

Descriptive analysis is used to present the basic characteristics of respondents' demographic backgrounds using frequency and percentage. There are five respondents' profiles which are to determine whether they are using cashless payment or not, gender, age, income level, and education level. In this research, 357 questionnaires were distributed in public which is generation $\mathrm{Z}$ and older generations. It shows that the frequency of using e-payment as one of the demographic information. Among 357 respondents, 328 of them use e-payment while the rest 29 respondents are not using e-payment. Based on the information gender, the size of male respondents is greater than female respondents. Among all of the respondents, male respondents have gathered 179 people, $50.1 \%$ for this research study. Other than that, 178 female respondents, which represents $49.9 \%$, are being conducted for this research.

The age below 18 years old consists of $0.3 \%$. The age of $18-25$ years old is the highest percentage among the age group. The 26 - 35 years old had $20.4 \%$ while the age of $36-45$ years old consist of $13.7 \%$. The $46-55$ years old is $3.4 \%$ which is the third lowest among the age group. The age above 55 years old is having the close percentage below 18 years old which is $0.6 \%$, the second lowest percentage among the age group. Based on the income level, there are $115(32.2 \%)$ respondents who have an income level below RM1000, 55 (15.4\%) respondents have income around RM1000 to RM2000, 119 (33.3\%) respondents have income between RM2000 to RM3000, 51 (14.3\%) respondents have the income about RM3000 to RM4000, and 17 (4.8\%) respondents have the income more than RM4000. Results for education level show that the amounts of respondents with SPM/O-level and STPM/A-level

are $33(9.2 \%)$ and $8(2.2 \%)$, respectively. $99(27.7 \%)$ of the respondents have a Diploma, 197 (55.2\%) respondents have Bachelor's Degree, and 13 (3.6\%) respondents have a Master's Degree. There are only $2(0.6 \%)$ and $5(1.4 \%)$ for the amounts of respondents who have $\mathrm{PhD}$ and Professional Certificate.

After the reliability test was carried out, the researcher found out that all of the variables showed great reliability. The Cronbach's Alpha value of social influences showed 0.944 , which is the highest value among all the variables. This indicates that social influences are the most reliable variable compared to others. Then, the second highest is compatibility, showed 0.903 . The variable of perceived usefulness and speed of transaction showed that the Cronbach's Alpha value is 0.869 and 0.843 , respectively, which fall under 0.9 to 0.8 . The business readiness and financial costs show the Cronbach's Alpha values for each variable are 0.758 and 0.735 , respectively.

In contrast, the value for personal security is 0.649 , which falls between 0.7 and 0.6. Lastly, the value for convenience and safer is 0.552 , which falls below 0.6 . Thus, the convenience and safer is considered poor reliability. Since the Cronbach's alpha of all variables is more than 0.6 except convenience and safer, the survey has to remove any question.

The normality test of generations $\mathrm{Z}$, shown that the skewness of speed of transaction (Skewness $=-1.181, \mathrm{M}=4.51, \mathrm{SD}=0.551)$ is considered as normal as they were in the range of -2 to +2 . Other than that, the value of skewness for personal security (Skewness $=-0.513, \mathrm{M}=4.07, \mathrm{SD}$ $=0.722$ ), convenience and safer (Skewness $=-0.900, \mathrm{M}=4.45, \mathrm{SD}=0.529$ ), social influences (Skewness $=-0.657, \mathrm{M}=4.09, \mathrm{SD}=0.907$ ), perceived usefulness (Skewness $=-0.598, \mathrm{M}=$ $4.47, \mathrm{SD}=0.562$ ), compatibility (Skewness $=-0.924, \mathrm{M}=4.34, \mathrm{SD}=0.733$ ), business Copyright $\odot$ GLOBAL ACADEMIC EXCELLENCE (M) SDN BHD - All rights reserved 
readiness (Skewness $=-0.033, \mathrm{M}=3.70, \mathrm{SD}=0.895)$ and financial costs (Skewness $=-0.362$, $\mathrm{M}=3.59, \mathrm{SD}=1.012$ ) further proven that the collected data are distributed normally as they fell in values between -1 to +1 .

The results for normality test of older generations, the skewness of personal security (Skewness $=-1.016, \mathrm{M}=4.23, \mathrm{SD}=0.808$ ) is considered as normal as they were in the range of -2 to +2 . Other than that, the value of skewness for speed of transaction (Skewness $=-0.919, \mathrm{M}=4.53$, $\mathrm{SD}=0.588$ ), convenience and safer (Skewness $=-0.399, \mathrm{M}=4.49, \mathrm{SD}=0.511$ ), social influences (Skewness $=-0.839, \mathrm{M}=4.22, \mathrm{SD}=0.832$ ), perceived usefulness (Skewness = $0.630, \mathrm{M}=4.42, \mathrm{SD}=0.580$ ), compatibility (Skewness $=-0.876, \mathrm{M}=4.35, \mathrm{SD}=0.714$ ), business readiness (Skewness $=-0.255, \mathrm{M}=3.71, \mathrm{SD}=0.897$ ) and financial costs (Skewness $=-0.276, \mathrm{M}=3.61, \mathrm{SD}=1.015)$ further proven that the collected data are distributed normally as they fell in values between -1 to +1 .

In this research, multiple linear regression analysis is used to determine the relationship between a dependent variable and independent variables that have been chosen. Table 1 till Table 3 below clearly specified result of multiple regression analysis on Generation Z. Table 1 shows the R-value of 0.483 denoted a robust relationship between cashless society and eight independent variables. The coefficient of determination, $\mathrm{R}$ square $=0.234$ stipulated that independent variable explained $23.4 \%$ variance in determinant factors of cashless society by Generation Z. The other $76.6 \%$ of the variance that remains unexplained means that other potential constructs would affect determinant factors of a cashless society in this study.

\section{Table 1: Model Summary of Multiple Regression Linear Analysis Generation $Z$}

\begin{tabular}{|c|c|c|c|c|}
\hline Model & $\mathrm{R}$ & R Square & $\begin{array}{c}\text { Adjusted R } \\
\text { Square }\end{array}$ & $\begin{array}{l}\text { Std. Error of the } \\
\text { Estimate }\end{array}$ \\
\hline 1 & $.483 a$ & .234 & .220 & .296 \\
\hline
\end{tabular}

Referring to Table 2, the p-value of 0.000 is below than alpha value of 0.05 , and its F-value is 16.510. This means that the regression model is fit for data. This result showed that the overall multiple regression model was significant at the 5\% level of significance. Moreover, the regression model indicated a good relationship between a cashless society's determinant factors and eight independent variables: speed of transaction, personal security, convenience and safer, social influences, perceived usefulness, compatibility, business readiness, and financial costs.

Table 2: ANOVA of Multiple Regression Linear Analysis-Generation Z

\begin{tabular}{cccc}
\hline Model & F & Sig. \\
\hline $\begin{array}{c}\text { Regression } \\
\text { Residual }\end{array}$ & 16.510 & $.000 \mathrm{~b}$ \\
\hline
\end{tabular}

Table 3 presented the coefficient of eight independent variables. Perceived usefulness had the highest standardized coefficient beta value of 0.197 . This indicated that perceived usefulness contributed higher significance to cashless society's determinant factors than other variables like speed of transaction, personal security, convenience and safer, social influences, compatibility, business readiness, and financial costs. Standardized coefficient beta value can also be denoted as a $1 \%$ increment in performance expectancy. It will result in a $0.197 \%$ increment in standard deviation of cashless society's determinant factors while other variables remain constant.

Copyright ( $)$ GLOBAL ACADEMIC EXCELLENCE (M) SDN BHD - All rights reserved 
Table 3: Coefficient of Multiple Regression Linear Analysis-Generation Z

\begin{tabular}{lrrrrrr}
\hline \multicolumn{1}{c}{ Factor } & $\begin{array}{c}\text { Unstandardized } \\
\text { Coefficient Beta }\end{array}$ & $\begin{array}{c}\text { Standardized } \\
\text { Coefficient } \\
\text { Beta }\end{array}$ & $\begin{array}{c}\mathrm{T} \\
\text { Value }\end{array}$ & $\begin{array}{c}\mathrm{P} \\
\text { Value } \\
\text { Sig. }\end{array}$ & Tolerance & VIF \\
\hline (Constant) & 2.111 & & 13.836 & .000 & \\
Speed of transaction & -.115 & -.188 & -3.606 & .000 & .651 & 1.536 \\
Personal security & -.082 & -.176 & -2.813 & .005 & .454 & 2.202 \\
Convenience and & -.086 & -.136 & -2.161 & .031 & .448 & 2.235 \\
safer & & & & & & \\
Social influences & .030 & .082 & 1.442 & .150 & .552 & 1.813 \\
Perceived usefulness & .118 & .197 & 3.353 & .001 & .512 & 1.953 \\
Compatibility & -.136 & -.297 & -4.527 & .000 & .410 & 2.436 \\
Business readiness & .054 & .143 & 2.834 & .005 & .698 & 1.434 \\
Financial costs & -.002 & -.005 & -.106 & .916 & .666 & 1.503 \\
\hline
\end{tabular}

A. Dependent Variable: Do You Use E-Payment?

Whereas for the unstandardized coefficient beta, perceived usefulness $(B=0.118)$ also played a main role in the variation of cashless society's determinant factors. To further interpret the unstandardized coefficient beta, every $1 \%$ increment of perceived usefulness would lead to $0.118 \%$ of increment in determinant factors of cashless society in this study. Overall, the regression coefficients reflected an equation that determine the relationship between independent variables (speed of transaction, personal security, convenience and safer, social influences, perceived usefulness, compatibility, business readiness and financial costs) and dependent variable (determinant factors of cashless society) as follow;

Determinant Factors of Cashless Society $=2.111-0.115$ (speed of transaction) -0.082 (personal security) -0.086 (convenience and safer) +0.030 (social influences) +0.118 (perceived usefulness) -0.136 (compatibility) +0.054 (business readiness) -0.002 (financial costs). Table 3 reveals that six variables have a significant relationship towards the determinant factors of a cashless society. Six of the variables such that speed of transaction $(p=0.000)$, personal security $(\mathrm{p}=0.005)$, convenience and safer $(\mathrm{p}=0.031)$, perceived usefulness $(\mathrm{p}=0.001)$, compatibility $(\mathrm{p}=0.000)$ and business readiness $(\mathrm{p}=0.005)$ are considered as significant towards the determinant factors of cashless society as they had p-value that lower than 0.05. Meanwhile, the other two variables are not significant such that social influences $(\mathrm{p}=0.150)$ and financial costs $(\mathrm{p}=0.916)$ had a $\mathrm{p}$-value that greater than 0.05 . On the other hand, three variables such that social influences $(B=0.030)$, perceived usefulness $(B=0.118)$, and business readiness $(B=0.054)$ shown that they had a positive relationship with the determinant factors of a cashless society as all of their unstandardized coefficient betas value were positive. Meanwhile, the other five variables, including speed of transaction $(B=-0.115)$, personal security $(B=-0.082)$, convenience and safer $(B=-0.086)$, compatibility $(B=-0.136)$, and financial costs $(B=-0.002)$, showed that they had a negative relationship with the determinant factors of a cashless society as all of their unstandardized coefficient betas value were negative.

Tolerance is the amount of variability in one independent variable that is no explained by other independent variables. Tolerance values less than 0.10 indicate collinearity. A small tolerance value indicates a high multicollinearity cut-off threshold which tolerance $<0.19$. In this research, all of the independent variables had a high tolerance value. Thus, there was no 
Volume 3 Issue 9 (September 2021) PP. 22-35 DOI 10.35631/AIJBES.39003

multicollinearity issue as each variable had a tolerance value that larger than 0.1 . This includes speed of transaction (0.651), personal security (0.454), convenience and safer $(0.448)$, social influences (0.552), perceived usefulness (0.512), compatibility (0.410), business readiness (0.698) and financial costs (0.666). To further access the multicollinearity issue, the researcher has examined the Variance Inflation Factor (VIF). VIF is reciprocal of tolerance. It is always greater than or equal to 1 . VIF values that exceed ten are considered multicollinearity. While for the weaker models, VIF values above 2.5 are regarded as multicollinearity. In accordance with Table 3, the researcher discovered that there is no multicollinearity between variables as each variable such that speed of transaction (1.536), personal security (2.202), convenience and safer (2.235), social influences (1.813), perceived usefulness (1.953), compatibility (2.436), business readiness (1.434) and financial costs (1.503) had VIF values that lower than both 10 and 2.5 .

Table 4 till Table 6 below clearly specified result of multiple regression analysis on Older Generation than Generation Z. R-value of 0.589 in Table 4 denoted a robust relationship between cashless society and eight independent variables of which speed of transaction, personal security, convenience and safer, social influences, perceived usefulness, compatibility, business readiness, and financial costs. The coefficient of determination, $\mathrm{R}$ square $=0.347$ stipulated that independent variable explained $34.7 \%$ variance in a cashless society's determinant factors. The other $65.3 \%$ of the variance that remains unexplained means that other potential constructs would affect a cashless society's determinant factors by the older generation in this study.

Table 4: Model Summary of Multiple Regression Linear Analysis- (Older generations)

\begin{tabular}{ccccr}
\hline Model & $\mathrm{R}$ & $\mathrm{R}$ Square & $\begin{array}{c}\text { Adjusted R } \\
\text { Square }\end{array}$ & $\begin{array}{c}\text { Std. Error of the } \\
\text { Estimate }\end{array}$ \\
\hline 1 & $.589 \mathrm{a}$ & .347 & .327 & .246 \\
\hline
\end{tabular}

Table 5 shows the p-value of 0.000 is below the alpha value of 0.05 , and its F-value is 17.452 , which means that the regression model is fit to the data. This result showed that the overall multiple regression model was significant at the 5\% level of significance. Moreover, the regression model indicated a good relationship between a cashless society's determinant factors and eight independent variables.

Table 5: ANOVA of Multiple Regression Linear Analysis (Older generations)

\begin{tabular}{cccc}
\hline Model & F & Sig. \\
\hline $\begin{array}{c}\text { Regression } \\
\text { Residual }\end{array}$ & 17.452 & $.000 \mathrm{~b}$ \\
\hline
\end{tabular}

A. Dependent Variable: Do You Use E-Payment?

Table 6 presented the coefficient of eight independent variables. Social influences had the highest standardized coefficient beta value of 0.492 . This indicates that social influences contributed higher significance to determinant factors of cashless society than other variables like speed of transaction, personal security, convenience and safer, perceived usefulness, compatibility, business readiness, and financial costs. Standardized coefficient beta value can also be denoted as a $1 \%$ increment in performance expectancy. It will result in $0.492 \%$ of increment in the standard deviation of cashless society's determinant factors while other variables remain constant. The unstandardized coefficient beta, convenience, and safer $(\mathrm{B}=$ 
Volume 3 Issue 9 (September 2021) PP. 22-35 DOI 10.35631/AIJBES.39003

0.250) played the main role in the variation of cashless society's determinant factors. To further interpret the unstandardized coefficient beta, every $1 \%$ increment of convenience and safer would lead to $0.250 \%$ of increment in determinant factors of a cashless society in this study.

Table 6: Coefficients of Multiple Regression Linear Analysis(Older generations)

\begin{tabular}{lrrrrrr}
\hline \multicolumn{1}{c}{ Factor } & $\begin{array}{c}\text { Unstandardized } \\
\text { Coefficient Beta }\end{array}$ & $\begin{array}{c}\text { Standardized } \\
\text { Coefficient } \\
\text { Beta }\end{array}$ & $\begin{array}{c}\text { T } \\
\text { Value }\end{array}$ & $\begin{array}{c}\text { P } \\
\text { Value } \\
\text { Sig. }\end{array}$ & Tolerance & VIF \\
\hline (Constant) & 1.619 & & 9.658 & .000 & & \\
& & & & & & \\
Speed of transaction & .095 & .187 & 1.675 & .095 & .200 & 5.002 \\
Personal security & -.050 & -.136 & -1.198 & .232 & .194 & 5.154 \\
Convenience and & .250 & .427 & 3.446 & .001 & .162 & 6.168 \\
safer & & & & & & \\
Social influences & .177 & .492 & 5.161 & .000 & .273 & 3.666 \\
Perceived usefulness & -.238 & -.460 & -3.083 & .002 & .111 & 8.970 \\
Compatibility & -.361 & -.860 & -6.333 & .000 & .135 & 7.429 \\
Business readiness & -.031 & -.092 & -1.146 & .253 & .386 & 2.589 \\
Financial costs & .034 & .115 & 1.430 & .154 & .381 & 2.621 \\
\hline
\end{tabular}

A. Dependent Variable: Do You Use E-Payment?

Overall, the regression coefficients reflected an equation that determines the relationship between independent variables (speed of transaction, personal security, convenience and safer, social influences, perceived usefulness, compatibility, business readiness, and financial costs) and dependent variable (determinant factors of cashless society) as follow:

Determinant Factors of Cashless Society $=1.619+0.095$ (speed of transaction) -0.050 (personal security) +0.250 (convenience and safer) +0.177 (social influences) -0.238 (perceived usefulness) -0.361 (compatibility) -0.031 (business readiness) +0.034 (financial costs).

Table 6 shown the p-value and unstandardized coefficient beta of 8 independent variables for Older generations. A P-value greater than 0.1 is considered insignificant, while a p-value that is lower than 0.1 is considered significant. The $\mathrm{p}$-value has to either greater or lower than 0.1 because, the confidence level being used is $90 \%$ instead of the normal $95 \%$. Hence, from this table, the researcher observed that five variables have a significant relationship with the cashless society's determinant factors. Five of the variables such that speed of transaction $(\mathrm{p}=0.095)$, convenience and safer $(\mathrm{p}=0.001)$, social influences $(\mathrm{p}=0.000)$, perceived usefulness $(\mathrm{p}=0.002)$, and compatibility $(\mathrm{p}=0.000)$ are considered as significant towards the determinant factors of a cashless society as they had p-value that lower than 0.05 .

Meanwhile, the other three variables are not significant such that personal security $(\mathrm{p}=0.232)$, business readiness $(\mathrm{p}=0.253)$, and financial costs $(\mathrm{p}=0.154)$, as they had a $\mathrm{p}$-value that greater than 0.05. On the other hand, four variables such that speed of transaction $(B=0.095)$, convenience and safer $(B=0.250)$, social influences $(B=0.177)$, and financial costs $(B=0.034)$ shown that they had a positive relationship with the determinant factors of a cashless society as all of their unstandardized coefficient betas value were positive. Meanwhile, the other 4 
Volume 3 Issue 9 (September 2021) PP. 22-35 DOI 10.35631/AIJBES.39003

variables, including personal security $(B=-0.050)$, perceived usefulness $(B=-0.238)$, compatibility $(B=-0.361)$, and business readiness $(B=-0.031)$ showed that they had a negative relationship with the determinant factors of a cashless society as all of their unstandardized coefficient betas value were negative.

Similar to Generation Z, all independent variables in Tables 6 had high tolerance values. Thus, there was no multicollinearity issue as each variable has a tolerance value that larger than 0.1 . To further access the multicollinearity issue, the researcher has examined the Variance Inflation Factor (VIF). Table 6 shows no multicollinearity between variables as each variable had VIF values that lower than 10 .

\section{Implications of the Study}

Based on the table above, four variables support both generations' relationship: Generations Z and Older generations between independent and dependent variables such as speed of transaction, convenience and safer, perceived usefulness, and compatibility. The variables that supported the relationship because the p-value in the coefficient are below 0.1 and 0.05 . The first variable that supported the relationship is the speed of transaction. The P-value for Generation $\mathrm{Z}$ and Older generations are 0.000 and 0.095 , respectively. The users agree that using cashless payment can increase transaction speed and save time as well. They also assume that transactions would be quick if they use cashless payment methods compared with conventional payment methods. Next, the second variable is convenience and safer. The Pvalue for Generation $\mathrm{Z}$ and Older generations are 0.031 and 0.001 , respectively. All generations assume the cashless payment completes the transaction faster than cash. Instead, they will use a cashless payment method only if it is easy to use, as the faster it is to use the payment system, the more likely they are to use it. Other than that, the third variable is perceived usefulness.

The P-value for Generation $\mathrm{Z}$ and Older generations are 0.001 and 0.002 , respectively. The users agree that using a cashless payment method is simple and understandable, and they also agree that it will be easy to use a cashless payment system. At the same time, it will be easy for them to learn to use the cashless payment method. The last variable is compatibility. The $\mathrm{P}$-value for Generation $\mathrm{Z}$ and Older generations are 0.000 and 0.000 , respectively. Generations $\mathrm{Z}$ and Older generations think that using cashless payment would suit their lifestyle and they also feel that using cashless payment methods is consistent with the way they like shopping. Instead, they feel they are suited to use cashless payment methods.

Table 4: Relationship Between Independent Variables And Dependent Variables

\begin{tabular}{|c|c|c|c|}
\hline \multicolumn{2}{|r|}{ Hypotheses } & Generations $\mathrm{Z}$ & Older \\
\hline H1 & $\begin{array}{l}\text { There is relationship between speed of } \\
\text { transaction and determinant factors of cashless } \\
\text { society. }\end{array}$ & Supported & Supported \\
\hline $\mathrm{H} 2$ & $\begin{array}{l}\text { There is relationship between personal security } \\
\text { and determinant factors of cashless society. }\end{array}$ & Supported & $\begin{array}{c}\text { Not } \\
\text { supported }\end{array}$ \\
\hline H3 & $\begin{array}{l}\text { There is relationship between convenience and } \\
\text { safer and determinant factors of cashless } \\
\text { society. }\end{array}$ & Supported & Supported \\
\hline $\mathrm{H} 4$ & $\begin{array}{l}\text { There is relationship between social influences } \\
\text { and determinant factors of cashless society. }\end{array}$ & Not supported & Supported \\
\hline
\end{tabular}


Volume 3 Issue 9 (September 2021) PP. 22-35 DOI 10.35631/AIJBES.39003

\begin{tabular}{cccc}
\hline H5 & $\begin{array}{l}\text { There is relationship between perceived } \\
\text { usefulness and determinant factors of cashless } \\
\text { society. }\end{array}$ & Supported & Supported \\
H6 & $\begin{array}{l}\text { There is relationship between compatibility and } \\
\text { determinant factors of cashless society. }\end{array}$ & Supported & Supported \\
H7 & $\begin{array}{l}\text { There is relationship between business readiness } \\
\text { and determinant factors of cashless society. }\end{array}$ & Supported & $\begin{array}{c}\text { Not } \\
\text { supported } \\
\text { Not }\end{array}$ \\
H8 & $\begin{array}{l}\text { There is relationship between financial costs and } \\
\text { determinant factors of cashless society. }\end{array}$ & Not supported & $\begin{array}{c}\text { Nopported } \\
\text { supher }\end{array}$ \\
\hline
\end{tabular}

\section{Conclusion}

The purpose of this study is to determine the factor influence cashless society in Malaysia. It divides into generation $\mathrm{Z}$ and older generation to identify whether there different factor among these generations. There are four similar factors influence both generations to become a cashless society. The speed of transaction, convenience and safer, perceived usefulness, and compatibility make Generation $\mathrm{Z}$ and the Older generation choose to use cashless in life. Both generations are ready to become cashless because cashless transactions are more convenient than cash. However, the government should give more information and encouragement to society on the benefits of using cashless payment methods to achieve Malaysia's target to become a cashless society by 2050 .

\section{References}

Achord, S., et al. (2017). A Cashless Society - Benefits, Risks and Issues. London: Institute and Faculty of Actuaries.

Albakri, D. (2017). Khairy:Malaysia to be cashless society by 2050. The Star Online. Retrieved from https://www.thestar.com.my/news/nation/2017/10/10/khairy-malaysiato- becashless society-by-2050.

Al-Khouri, A.M. (2014). Electronic Payments and Social Inclusion. Research Academy of Social Science, 3(4), 247-251.

Amin, H., Hamid, M. R. A., Lada, S., \& Anis, Z. (2008). The adoption of mobile banking in Malaysia: The case of Bank Islam Malaysia Berhad. International Journal of Business and Society, 9(2), 43-53

Anyaegbunam, F.N.C (2014). Electronic Alternative to Raw Cash: Advent of A Cashless Society. International Journal of Engineering Research \& Technology (IJERT), 3(2), 2365-2372.

Chmielarz, W., \& Zborowski, M. (2018). Determinants of using project management in the implementation of information systems. Procedia Computer Science, 126, 1224-1236.

Chelawat, H. \& Trivedi, I. V. (2014). Implications of Emerging Electronic Payment Systems in India: A Strategic Overview. Journal of Multidisciplinary Research, 6(3), 53.

Cronbach, L.J. (1951). Coefficient Alpha and the Internal Structural of Test. Psychometrika, 16(3), 297-334.

Ejoh, N, O. Adebisi, A, W. Okpa, I, B. (2014) "Information and Communication TechnologyAn Indispensable Tool for the Implementation of Cash-less Policy in Nigeria" International Journal of Economics, Commerce and Management. 11(10) pp., 1-18.

Filona, F., \& Misdiyono, M. (2019). Factors affecting the adoption of electronic money using technology acceptance model and theory of planned behavior. Jurnal Ilmiah Ekonomi Bisnis, 24(1), 108-120. 
Volume 3 Issue 9 (September 2021) PP. 22-35 DOI 10.35631/AIJBES.39003

Hair et. al. (2006). Multivariate Data Analysis (Sixth Edition). Pearson Prentice Hall, Upper Saddle River, N.J.

Lazo, B.B., Karlsson, T. \& Thodenius, B. (2014). The origins of the cashless society: cash dispensers, direct to account payments and the development of online real-time networks, C. 1965-1985. Essays in Economic \& Business History Volume XXXII.

Liébana-Cabanillas, F., Ramos de Luna, I., \& Montoro-Ríos, F. J. (2015). User behaviour in QR mobile payment system: the QR Payment Acceptance Model. Technology Analysis \& Strategic Management, 27(9), 1031-1049.

Nuwagaba, A (2014) "Reality of Having a Cashless Society in Rwanda: Case Study- National Bank of Rwanda" International Journal of Business and Management Invention. 3(3) pp., 63-69.

Odumeru, J.A. (2013). Going Cashless: Adoption of Mobile Banking in Negeria. Arabian Journal of Business and Management Review (Nigerian Chapter), 1(2), 9-17.

Rogers, E.M. (1995). Diffusion of innovations, Fourth Edi. The Free Press, New York.

Swartz, D.D.G., Hahn, R.W., \& Farrar, A.L. (2006). The Move Toward a Cashless Society: A Closer Look at Payment Instrument Economics. Review of Network Economics, 5(2), 175-198.

Taylor, S. \& Todd, P. A. (1995). Understanding information technology usage: A test of competing models. Information systems research, 6(2), 144-176.

Tee, H. \& Ong, H. (2016). Cashless payment and economic growth. Financial Innovation 2, 4.

Thomas, L.D.W., Vernet, A. \& Gann, D.M. (2014). Digital Money: How Ready are Countries to Adopt? DRUID Society Conference.

Trinugroho, et al. (2017). How Ready Are People For Cashless Society? Jurnal Keuangan dan Perbankan, 21(1), 105-102.

Venkatesh, V., Morris, M. G., Davis, G. B., and Davis, F. D. 2003. "User Acceptance of Information Technology: Toward a Unified View," MIS Quarterly (27:3), pp. 425-478.

Worthington, S. (1995). The Cashless Society. International Journal of Retail \& Distribution Management, 23(7), 31-40.

Wulandari, D., Soseco, T., \& Narmaditya, B. S. (2016). Analysis of the use of electronic money in efforts to support the less cash society. International Finance and Banking, 3(1), 110.

Yadav, P. (2017). Active Determinants for Adoption of Mobile Wallet. i-manager's Journal on Management, Vol. 12, No. 1. 